\title{
Improvements of the method for the preparation of an artificial prothrombin reagent
}

Citation for published version (APA):

Vermeer, C., Soute, B. A. M., \& Hemker, H. C. (1978). Improvements of the method for the preparation of an artificial prothrombin reagent. Thrombosis Research, 12(4), 713-716. https://doi.org/10.1016/00493848(78)90264-5

Document status and date:

Published: 01/01/1978

DOI:

10.1016/0049-3848(78)90264-5

Document Version:

Publisher's PDF, also known as Version of record

\section{Please check the document version of this publication:}

- A submitted manuscript is the version of the article upon submission and before peer-review. There can be important differences between the submitted version and the official published version of record.

People interested in the research are advised to contact the author for the final version of the publication, or visit the DOI to the publisher's website.

- The final author version and the galley proof are versions of the publication after peer review.

- The final published version features the final layout of the paper including the volume, issue and page numbers.

Link to publication

\footnotetext{
General rights rights.

- You may freely distribute the URL identifying the publication in the public portal. please follow below link for the End User Agreement:

www.umlib.nl/taverne-license

Take down policy

If you believe that this document breaches copyright please contact us at:

repository@maastrichtuniversity.nl

providing details and we will investigate your claim.
}

Copyright and moral rights for the publications made accessible in the public portal are retained by the authors and/or other copyright owners and it is a condition of accessing publications that users recognise and abide by the legal requirements associated with these

- Users may download and print one copy of any publication from the public portal for the purpose of private study or research.

- You may not further distribute the material or use it for any profit-making activity or commercial gain

If the publication is distributed under the terms of Article $25 \mathrm{fa}$ of the Dutch Copyright Act, indicated by the "Taverne" license above, 
THROMBOSIS RESEARCH

Printed in Great Britain
Vo1. 12, pp. 713-716, 1978

Pergamon Press, Ltd.

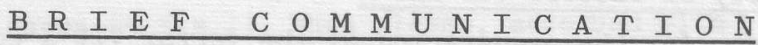

IMPROVEMENTS OF THE METHOD FOR THE PREPARATION OF AN ARTIFICIAL PROTHROMBIN REAGENT

C.Vermeer, B.A.M. Soute and H.C.Hemker

Department of Biochemistry, State University Limburg, Maastricht, The Netherlands

(Received 14.12.1977; in revised form 23.2.1978. Accepted by Editor L. Vroman)

\section{INTRODUCTION}

About two years ago we developed a method to prepare a prothrombin-free reagent for the one-stage determination of prothrombin. The reagent was devoid of any prothrombin and had an infinite buffer time (1). The preparation procedure of the reagent was:

a. oxalate plasma was adsorbed three times with $100 \mathrm{mg} / \mathrm{ml}$ of $\mathrm{BaSO}_{4}$

b. serum was prepared from oxalate plasma by adding Echis Carinatus venom and $\mathrm{CaCl}_{2}$. The serum was adsorbed to DEAE Sephadex and after washing the Sephadex the factors VII and $\mathrm{X}$ were eluted by a step elution, dialyzed and added to the $\mathrm{BaSO}_{4}$ adsorbed plasma.

During the last two years we have prepared more than 20 batches of the bovine reagent and in this communication we report several improvements of the preparation procedure which were made during these two years.

\section{MATERIALS AND METHODS}

Buffer $\mathrm{A}: 0.15 \mathrm{M} \mathrm{NaCl}, 0.005 \mathrm{M}$ Tris-HCl, $\mathrm{pH} 7.9$. Buffer $\mathrm{B}: 1.0 \mathrm{M} \mathrm{NaCl}, 0.005 \mathrm{M}$ Tris-HC1, $\mathrm{pH} 7.0$. Buffer $\mathrm{C}: 0.0286 \mathrm{M}$ sodium acetate, $0.0286 \mathrm{M}$ sodium barbiturate, $0.1164 \mathrm{M} \mathrm{NaC1}, \mathrm{pH} 7.4$. Oxalate and citrate plasma were prepared by collecting blood in $0.1 \mathrm{M}$ disodium oxalate $(10 \% \mathrm{v} / \mathrm{v})$ or in $0.1 \mathrm{M}$ trisodium citrate $(10 \% \mathrm{v} / \mathrm{v})$ followed by centrifugation for $30 \mathrm{~min}$ at $4,000 \mathrm{x} \mathrm{g}$. 
Coagulation tests were performed by incubating $0.1 \mathrm{ml}$ reagent, $0.1 \mathrm{ml}$ thromboplastin (2) and $0.1 \mathrm{ml}$ sample at $37^{\circ} \mathrm{C}$ for $30 \mathrm{sec}$. The reaction was started by adding $0.1 \mathrm{ml} \mathrm{CaCl}{ }_{2}$ solution $33 \mathrm{mM}$. Normal pool plasma was obtained from 30 cows and plasma dilutions were prepared in buffer $C$.

\section{RESULTS}

\section{a. Improved recovery of factors VII and $X$}

Using oxalate plasma for the preparation of the.factor VII-X concentrate, we noticed that the recovery of factor $X$ varied from one experiment to the other, and that it was always lower than we expected. As is shown in Table I, the amount of factor II (prothrombin) was independent of the anticoagulant solution, but the level of factors VII and $X$ appeared to be higher in citrate plasma than in oxalate plasma, probably because these factors adsorb part $1 y$ on the calcium oxalate, formed during the collection of blood and after recalcification of the plasma (3). Therefore citrate plasma should be used for the production of the factor VII-X concentrate.

\section{TABLE I}

The Amount of Clotting Factors in Plasma

\begin{tabular}{|l|c|c|}
\hline \multicolumn{2}{|c|}{$\begin{array}{c}\text { Concentration of clotting factor }(\mathrm{U} / \mathrm{m} 1) \text { in } \\
\text { citrate plasma } \\
\text { oxalate plasma }\end{array}$} \\
\hline Factor II & 1.00 & 1.00 \\
Factor VII & 1.00 & 0.68 \\
Factor X & 1.00 & 0.87 \\
\hline
\end{tabular}

b. The amount of Echis Carinatus venom to be added

At several occasions it appeared that a minute amount of prothrombin had not reacted with the Echis Carinatus venom. Even the addition of $5 \mathrm{mg}$ of venom per litre of plasma (a five-fold amount) sometimes left residual amounts of prothrombin. The concentration of unreacted prothrombin was below the detection range but still ilupaired the properties of the reagent (a buffer time of 5-15 min was observed). These last traces of prothrombin can be removed from the dialyzed factor VII-X concentrate by repeating the Echis Carinatus treatment, DEAE-Sephadex adsorption and elution procedure.

c. Removal of antithrombin III

Tne $\mathrm{BaSO}_{4}$ adsorbed plasma still contains thrombin inhibitors, the major part of which consists of antithrombin III. In some cases the level of inhibitor was so high that it caused deviations in the reference curve ( $t-D$ plot). As was published earlier (4), this curve should be rectilinear when the clotting time is plotted against the dilution of clotting factor. The presence of thrombin inhibitors, however, caused higher clotting times than expected, 
especially at prothrombin concentrations lower than $0.003 \mathrm{U} / \mathrm{ml}$. In the range between 0.1 and $0.003 \mathrm{U} / \mathrm{ml}$ hardly any deviation could be detected. The antithrombin activity could be efficiently removed by adding $\mathrm{Al}(\mathrm{OH})_{3}(5 \% \mathrm{w} / \mathrm{v})$ to the $\mathrm{BaSO}_{4}$ adsorbed plasma. $\mathrm{Al}(\mathrm{OH})_{3}$ is known to bind antithrombin III (5). After stirring for $30 \mathrm{~min}$ and centrifuging ( $15 \mathrm{~min}, 10,000 \mathrm{x} \mathrm{g}$ ), the plasma was used to prepare a prothrombin reagent, which was compared to the normal reagent. This is shown in fig. 1. When plasma, adsorbed with both, $\mathrm{BaSO}_{4}$ and $\mathrm{A} 1(\mathrm{OH})_{3}$ was used for preparing the prothrombin reagent, the $t-D$ plot is rectilinear, whereas the reagent from plasma, adsorbed with $\mathrm{BaSO}_{4}$ only, gives a curved $t-D$ plot, especially at very low concentrations of prothrombin.

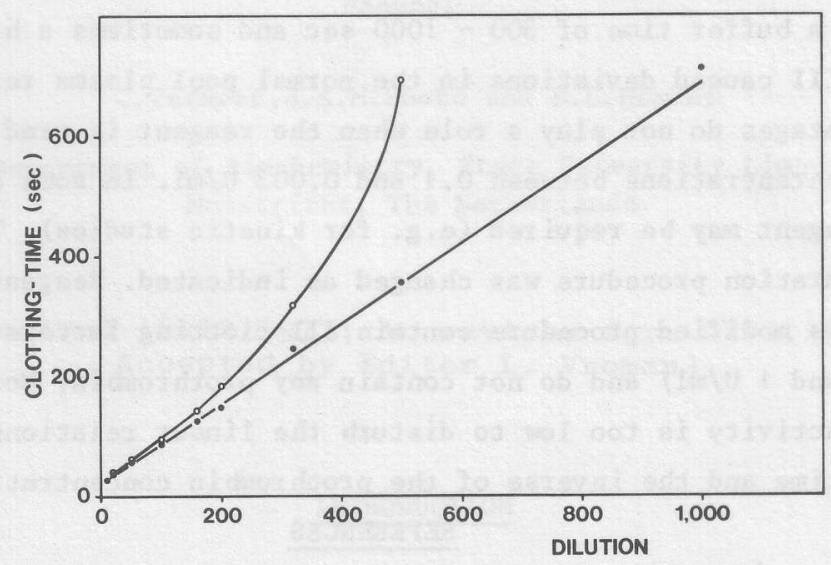

FIG. 1 .

Reference curves of varying prothrombin reagents. $\mathrm{BaSO}_{4}$-adsorbed plasma (see text) was adsorbed with $\mathrm{Al}(\mathrm{OH})_{3}$. The plasma before and ${ }^{4}$ after $\mathrm{Al}(\mathrm{OH})_{3}$ treatment was used to prepare a prothrombin reagent. Reference curves of normal pool plasma were made with $\mathrm{Al}(\mathrm{OH}) 3^{\text {treated }}(\bullet-\bullet)$ and the non-treated $(\mathrm{O}-\mathrm{O})$ reagent.

d. Method of preparation of the prothrombin reagent

The experiments shown above lead to the following nreparation procedure:

a. oxalate plasma is adsorbed three times with $\mathrm{BaSO}_{4}(100 \mathrm{mg} / \mathrm{ml})$ and once with $\mathrm{Al}(\mathrm{OH})_{3}(5 \% \mathrm{w} / \mathrm{v})$.

b. citrate plasma is recalcified and Echis Carinatus venom ( $5 \mathrm{mg} / 1)$ is added. After incubation for 2 hours at $37^{\circ} \mathrm{C}$ the clot is disrupted and removed by centrifugation ( $30 \mathrm{~min}$ at $40,000 \times \mathrm{g}$ ). The serum is adsorbed on to DEAE Sephadex ( $15 \mathrm{ml}$ of slurry per litre of serum) by stirring for 1 hour and the Sephadex is brought into a column, washed with buffer A (200 ml per litre of serum) and eluted stepwise with buffer $B$. The eluate is dialyzed against buffer $\mathrm{A}$ and tested for its prothrombin content by adding $\mathrm{BaSO}_{4}$ adsorbed plasma to a sample of the factor VII-X concentrate and measuring 
its buffer time. When a buffer time is found (that means: when some prothrombin is left) a second Echis Carinatus treatment may be performed. The dialyzed factor VII- $X$ concentrate is added to the $\mathrm{BaSO}_{4}$-adsorbed plasma in such a way that factor $X \geqslant 1 \mathrm{U} / \mathrm{m} 1$. (Usually about $100 \mathrm{~m} 1$ concentrate per litre of plasma).

\section{DISCUSSION}

In 1976 , we published an easy method for the preparation of an artificial prothrombin-free prothrombin reagent (1). The bovine reagent, however, was not always of a constant quality, probably due to variations of the level of some plasma proteins in different cows. Sometimes a small amount of prothrombin was left, causing a buffer time of $300-1000 \mathrm{sec}$ and sometimes a high level of antithrombin III caused deviations in the normal pool plasma reference curve. These disadvantages do not play a role when the reagent is used for measuring prothrombin concentrations between 0.1 and $0.003 \mathrm{U} / \mathrm{ml}$. In some cases, however, an optimal reagent may be required (e.g. for kinetic studies). Therefore, the original preparation procedure was changed as indicated. Reagents prepared according to this modified procedure contain all clotting factors in excess (between 0.4 and $1 \mathrm{U} / \mathrm{ml}$ ) and do not contain any prothrombin. Moreover, the antithrombin activity is too low to disturb the linear relationship between the clotting time and the inverse of the prothrombin concentration.

\section{REFERENCES}

1. VERMEER, C., SOUTE,B.A.M. and HEMKER,H.C. A new method for the preparation of artificial factor II reagents from normal human and bovine plasma. Thrombosis Research 10, 495-507, 1976.

2. OWREN,P.A. and AAS, K. The control of dicoumarol theory and the quantitative determination of prothrombin and proconvertin. Scand.J.Clin.Lab. Invest. $3,201-218,1951$.

3. SUTTIE, J.W. and JACKSON, C.M. Proth rombin structure, activation and biosynthesis. Pings.Rev. 57, 1-59, 1977.

4. HEMKER,H.C.,HEMKER,P.W., and LOELIGER,E.A. Kinetic aspects of the interaction of blood clotting enzymes. I. Derivation of basic formulas. Thrombos.Diathes.haemorrh. 13, 155-175, 1965.

5. ABILDGAARD, U. Purification of two progressive antithrombins of human plasma. Scand.J.Clin.Lab.Invest. 19, 190-195, 1967. 